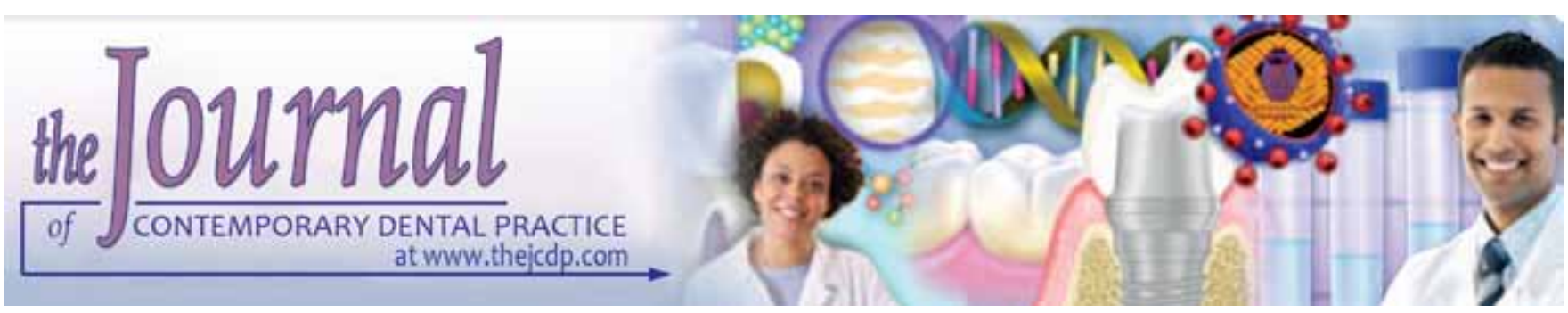

\title{
The Effects of Ionizing Radiation on the Oral Cavity
}

\author{
${ }^{1}$ Sandra Ribeiro de Barros da Cunha, ${ }^{2}$ Pedro Augusto Mendes Ramos, ${ }^{3}$ Ana Cristina Aló Nesrallah \\ ${ }^{4}$ Cláudia Joffily Parahyba, ${ }^{5}$ Eduardo Rodrigues Fregnani, ${ }^{6}$ Ana Cecília Corrêa Aranha
}

\section{ABSTRACT}

Aim: The aim of this study is to present a literature review on the effects of the ionizing radiation from radiotherapy treatment on dental tissues.

Background: Among the effects of increasing global life expectancy and longevity of the teeth in the oral cavity, increasing rates of neoplastic diseases have been observed. One of the important treatment modalities for head and neck neoplastic diseases is radiotherapy, which uses ionizing radiation as the main mechanism of action. Therefore, it is essential for dentists to be aware of the changes in oral and dental tissues caused by ionizing radiation, and to develop treatment and prevention strategies.

Results: In general, there is still controversy about the effects of ionizing radiation on dental structures. However, qualitative and quantitative changes in saliva and oral microbiota, presence of oral mucositis and radiation-related caries are expected, as they represent the well-known side effects of treatment with ionizing radiation. Points that still remain unclear are the effects of radiotherapy on enamel and dentin, and on their mechanisms of bonding to contemporary adhesive materials.

Conclusion: Ionizing radiation has shown important interaction with organic tissues, since more deleterious effects have been shown on the oral mucosa, salivary glands and dentin, than on enamel.

Clinical significance: With the increasing number of patients with cancer seeking dental treatment before and after head and

\footnotetext{
${ }^{1,6}$ Department of Restorative Dentistry, School of Dentistry University of São Paulo, São Paulo, Brazil

${ }^{2}$ Department of Radiotherapy, Hospital Sírio Libanês, São Paulo, Brazil

${ }^{3-5}$ Department of Oral Medicine, Hospital Sírio Libanês, São Paulo, Brazil
}

Corresponding Author: Sandra Ribeiro de Barros da Cunha PhD Student, Department of Restorative Dentistry, School of Dentistry, University of São Paulo, São Paulo, Brazil, Phone: +55 11 30917645, e-mail: sandra.cunha@gmail.com neck radiotherapy, it is important for dentists to be aware of the effects of ionizing radiation on the oral cavity.

Keywords: Dental tissues, Head and neck cancer, lonizing radiation, Radiotherapy.

How to cite this article: de Barros da Cunha SR, Ramos PAM, Nesrallah ACA, Parahyba CJ, Fregnani ER, Aranha ACC. The Effects of lonizing Radiation on the Oral Cavity. J Contemp Dent Pract 2015;16(8):679-687.

\section{Source of support: Nil}

\section{Conflict of interest: None}

\section{INTRODUCTION}

During the last decades, there has been a substantial improvement in the treatment of head and neck cancer, and radiotherapy is currently a widely used and important part of this treatment. ${ }^{1}$ In comparison with surgical procedures, it shows better results because it can be used as a curative, adjuvant, neoadjuvant and palliative type of treatment, and is often used in conservative approaches, with protocols that preserve organs and tissues. ${ }^{2}$ Ionizing radiation is considered a corpuscular or electromagnetic wavelength that carries energy and when energy interacts with the tissues, it causes fast movement of electrons, which ionize the chemical environment and produce effects, such as water hydrolysis and DNA modifications. Cell death can result from several mechanisms. ${ }^{3}$

Head and neck radiotherapy consists of cumulative doses that are mostly fractionated and delivered in daily sessions with pauses on weekends. The treatment usually lasts for about 7 weeks and its total doses range from 40 to 70 Gy. ${ }^{4-8}$

Since radiotherapy interacts with healthy surrounding tissues, it can cause different side effects. Although new techniques, such as intense-modulated radiotherapy (IMRT), make it possible that the primary target receives the total amount of radiation while the adjacent healthy tissue receives the lowest possible amount of secondary 
doses, it is still common to observe changes in salivary gland structures and saliva properties, since salivary glands are very radiosensitive. ${ }^{9-12}$ Furthermore, changes in oral microflora may be linked to the changes in saliva, since the oral cavity becomes more acidic with the decrease in saliva $\mathrm{pH} .{ }^{13-17}$

It should be pointed out that these changes in the oral microflora may act as a factor for the development of oral mucositis, as well as for the development of radiationrelated caries. ${ }^{18}$ Moreover, hard tissue modifications are considered a side effect of radiotherapy. However, this controversial topic should be studied with caution since there are different results and opinions described in the literature.

In addition to the changes in saliva, oral microflora and possible hard tissue alterations, radiation-related dental caries is another multifactorial complication that may occur after radiation, tends to develop in the first year and become more severe over time, leading to emotional and physical harm to the patient. ${ }^{19}$

In the past, no information about the exact effects of ionizing radiation on the oral tissues was known by the dentists. As a consequence, full mouth extractions were prescribed before radiotherapy and with all the oral changes that occurred, the prosthesis were not well tolerated by the patient. Nowadays, with all information provided, there is no doubt that the best option for these patients is to maintain as many healthy teeth as possible. ${ }^{19-22}$

Since radiotherapy is a common head and neck cancer treatment and its effects are extremely important for the management of dental treatment, the aim of this article is to review these effects on oral environment and on dental hard tissues.

Pubmed and ISI web of knowledge search engines were used, and articles relevant to clinicians were selected.

\section{EFFECTS ON SALIVARY GLANDS}

The major oral surrounding tissues that present important side effects when interacting with ionizing radiation from radiotherapy are the salivary glands. These tissues usually receive secondary doses from those delivered to the head and neck tumors, and although they have a low mitotic rate, salivary glands are considered extremely radiosensitive. ${ }^{11}$

While radiation damage to salivary glands is well known in the clinic by its sides effects, it is not known exactly what mechanism of destruction the ionizing radiation have on salivary glands. However, it is known that serous acini are more radiosensitive than mucous acini. ${ }^{11,23}$ Some studies have shown that after the first fractionated dose of radiotherapy, serous were modified, while the mucous acini remained intact. ${ }^{9-11}$ It is known that fibrosis and glandular atrophy begin immediately after the treatment and they intensify until treatment ends. These effects cause a rapid and irreversible reduction in salivary flow. ${ }^{9-11}$ Some authors have stated that depending on the radiation field, after radiation with only $20 \mathrm{~Gy}$, approximately $80 \%$ of salivary function is lost, and after 30 Gy the damage caused seems to be permanent. By the end of radiotherapy, salivary flow is reduced by up to $95 \%$. $^{8,13,24-27}$

In addition to the changes in the quantity of saliva, qualitative changes also occur. There have been reports of an increase in saliva viscosity, changes in the antibacterial properties and consequent alteration in the oral microflora. Moreover, saliva $\mathrm{pH}$ decreases to about five. All these changes also reduce the buffer capacity and modify the concentration of saliva ions. As a result of the reduction in $\mathrm{pH}$ and buffering capacity, the demineralization/ remineralization system is thrown out of balance, and the equation moves to the demineralization side, making it easier for the minerals found in enamel and dentin to be demineralized after radiotherapy. ${ }^{13-17}$

Simultaneously to the qualitative and quantitative changes in saliva, the oral microbiota is also altered. Xerostomia caused by radiotherapy results in an immunological and protein deficit and an increase in the number of acidogenic and cariogenic microorganisms, such as the rise in concentration of Streptococcus mutans, Actinomyces and Lactobacillus, while the concentration of Nisseria, Fusobacterium and Streptococcus sanguis is decreased. ${ }^{25}$ In addition, oral Candida albicans infections are frequently observed in patients, both during and after the radiation treatment. ${ }^{25,28-30}$

\section{ORAL MUCOSITIS}

Oral mucosa responds quickly to ionizing radiation with the appearance of oral mucositis, an inflammatory reaction of the mucous membranes due to the loss of squamous epithelial cells by mitotic death of basal keratinocytes, which may occur in esophageal, pharyngeal, laryngeal areas, and in the oral cavity, also linked with changes in the oral microflora. ${ }^{14,31-34}$

Oral mucositis is a painful, multifactorial inflammation that usually appears in the beginning of head and neck radiotherapy and persists until the 3rd week after the end of treatment. ${ }^{14,35}$ Since oral mucositis can be very painful, it makes it difficult for patients to eat, and leads to nutritional deficiency. ${ }^{36}$ To avoid enteral nutrition by tube, the patient's diet becomes more frequent and rich in carbohydrates. ${ }^{13,14,36,37}$ 
Oral mucositis does not have an infectious etiology, but secondary microbial colonization in the lesions can cause a systemic or local infection that can exacerbate mucositis. 33

The onset of oral mucositis depends on the radiation dose and the fractionation schedule. Nearly all patients that receive head and neck radiotherapy will develop this inflammatory reaction. ${ }^{34}$ In more traditional treatments, with duration of 6 to 7 weeks, at doses of 2 Gy per day, 5 days a week, oral mucositis usually appears at the 2nd week of treatment, and persists until the 3rd week after the end of treatment. ${ }^{14,35}$ Symptoms of oral mucositis include pain, dysgeusia (distortion or decreased sense of taste), dysphagia (difficulty in swallowing) and odynophagia (painful swallowing). ${ }^{32}$ Oral mucositis may also indirectly affect the teeth, as oral hygiene may be impaired and when associated with other factors, such as changes in oral microflora, decreased buffering capacity of saliva and changes in diet, increases the risk of caries and periodontal diseases. ${ }^{14}$

The pain from oral mucositis associated with dysphagia, odynophagia, nausea and loss of appetite causes the patient to lose a significant amount of weight. Physicians and nutritionists should change the patient's diet, increasing the frequency and quantity of carbohydrates to avoid enteral nutrition and improve the quality of life. ${ }^{13,14,37}$ Currently, there are not well defined protocols for the treatment or prevention of oral mucositis, but the irradiation with low power lasers is described as being a complementary treatment tool in the prevention and treatment of oral mucositis lesions, with significant and important results. ${ }^{33,34}$

\section{RADIATION-RELATED DENTAL CARIES}

The literature about the effects of ionizing radiation on dental structure is still controversial. With regard to the radiosensitivity of specialized dental cells, there are studies that have reported that ameloblasts have a less sensitive response to ionizing radiation than odontoblasts. ${ }^{39}$ A study with incisors in mandibles and jaws of mice observed that radiation affects odontogenesis. ${ }^{1,40}$ It is known that the severity and extension of damage caused by ionizing radiation in dental tissues depends on the area affected by the radiation, radiation dose, and mineral and organic content of tooth structures. ${ }^{41}$

In the clinic, the lesion frequently appears as a diffuse brown discoloration on the smooth enamel surface, with rapid progression and is usually not associated with severe pain. ${ }^{6,42}$ Typical dental caries usually occur in fissures and interproximal areas of the teeth, while radiation decay tends to occur at the dentinoenamel junction, cusps, incisal (regions exposed to occlusal load) and cervical (associated with flexion) areas, sites considered more resistant to regular dental caries. ${ }^{14}$

Despite the relationship between radiation and dental caries not being well documented, it is important to note that although caries from irradiated patients differ considerably in clinical appearance, radiationrelated caries seems to have the same morphological and demineralization pattern as ordinary caries. Silva et al, in their study, found the presence of demineralized dentin, translucent zone, dead tracts in dentin, reactionary dentin and intratubular dentin deposition; they concluded that ionizing radiation does not seem to be essential to the microscopic progression of radiation-related caries. ${ }^{42}$

Clinical observations have suggested that higher the radiation dose is, the more severe lesions will occur. ${ }^{14}$

Radiation-related caries appear only in patients undergoing radiotherapy; thus, it is well-known that the changes caused in salivary glands, saliva, oral flora, the occurrence of oral mucositis, diet changes and decrease in the standard of oral hygiene are important factors for the onset of this multifactorial disease. The aspect/topic that still needs more research concerns the direct effect of ionizing radiation on dental tissues and its consequences for the onset of radiation-related caries.

There is a lack of randomized clinical trials for radiationrelated caries treatment, so the recommendation of treatments is mainly based on clinical experience. ${ }^{6}$

The use of neutral fluorides is preferable in patients with xerostomia, since acidified gels could cause harmful effects on the oral mucosa and teeth, the enamel would be dissolved and the decreased salivary flow would hamper the remineralization process. ${ }^{6}$ Therefore, with a daily topical application of $1 \%$ neutral sodium fluoride gel, using a custom tray, caries occurrence seems to be greatly reduced..$^{6,18,43,44}$ There have been reports that fluoride application every 2 days is more effective than daily rinses with fluoride solutions. ${ }^{45-47}$

For plaque control, daily chlorhexidine mouthwashes should be used in conjunction with a normal daily toothbrushing with a soft brush. ${ }^{6,13}$ The prevention of hyposalivation also helps to prevent radiation caries. ${ }^{45}$

Nevertheless, all these methods of care may be not enough to prevent radiation-related caries. The dentist will find several complications in the restoration procedure, such as trismus, pain from oral mucositis, difficulty to perform appropriate soft dentinal caries removal, cavity preparation and little mechanical retention. ${ }^{13,48,49}$ As regards the restorative material, there is a lack of studies and thus, there is no gold standard of restorative treatment. Composite resins appear to be the restorative material of choice. They have been shown to prevent in vitro 
recurrent caries, good retention due to their bonding potential, sealing ability and marginal adaptation in the long-term. ${ }^{13,45,50}$

As far as glass ionomer is concerned, the literature has demonstrated that xerostomia causes dehydration and loss of the material because of the reduced salivary buffer capacity, decrease in oral $\mathrm{pH}$ and formation of hydrofluoric acid resulting in rough and plaque retentive margins, causing a serious problem of loss of material. ${ }^{13,45,51}$ Modern glass ionomer materials appear to have better resistance against abrasion and reduced solubility resulting in better protection against erosion, but not on a hyposalivation situation. ${ }^{45,52,53}$ However, as these materials release fluoride into the oral cavity, and help to prevent secondary caries, they would be the optimal choice for temporary treatment of cervical radiationrelated caries. When the glass ionomer fails because of the erosion, it may be replaced with composite resin or with a sandwich technique (when a composite resin is used to cover the remains of the glass ionomer). ${ }^{45}$

\section{CHANGES IN ORAL HARD TISSUES}

As regards the effects of ionizing radiation on the hard dental tissues, there are still doubts and contradictions. It is well described in literature that the organic part of dental tissues is more susceptible to the effects of radiotherapy. ${ }^{1,53-55}$ This could be related to the fact that dentin microhardness is affected by ionizing radiation, whereas there are still some contradictions in the literature about the properties of enamel after radiotherapy. ${ }^{56-58}$

With respect to enamel, there is no agreement about the exact consequences for this substrate when it interacts with ionizing radiation. The literature reports that there is destruction of prismatic structures in irradiated enamel resulting in a demineralization pattern that differs from that of nonirradiated enamel. ${ }^{8,56,59}$ A study in rats has indicated the loss of organization in enamel prisms after doses higher than $0.5 \mathrm{~Gy}{ }^{1}$ Reports have indicated that the interaction of ionizing radiation with the enamel structure reduces its mechanical properties. ${ }^{60}$ It has been seen that the apatite crystals eventually incorporate sodium, carbonate and magnesium ions during their formation when undergoing radiotherapy. These retained ions can be removed and modify the structure of crystals, changing the physical structure of enamel. ${ }^{41,61,62}$ Nevertheless, enamel demineralization is a controversial topic in the current literature. Some studies have indicated no difference between the patterns of in vitro demineralization and in situ remineralization, concluding that the enamel interaction with ionizing radiation is not the main cause of the initial enamel demineralization in patients with xerostomia caused by radiotherapy. ${ }^{6,57,63}$ Other studies have reported that irradiated enamel shows greater resistance to acid attack. ${ }^{8,64,65}$ An in vitro and in situ study stated that no difference in mineral loss or depth of caries lesions was observed in irradiated enamel. ${ }^{57}$ In a more recent article, it was demonstrated that with doses of up to $30 \mathrm{~Gy}$, a decrease in enamel microhardness was observed, while doses from 40 to 60 Gy showed no statistical difference in mean microhardness values, when compared with the control group. ${ }^{58}$

Other authors have stated that enamel microhardness is not affected by ionizing radiation, and suggested that any changes in the mineral structure caused by radiotherapy, are more likely to be due to chemical interactions rather than physical changes. A great part of the literature declares that the effects of ionizing radiation in therapeutic doses has greater effects on organic components than on mineral content. ${ }^{61,65}$

With regard to microhardness in dentin, it has been stated that this property decreases after only $10 \mathrm{~Gy}$, and with doses higher than 60 Gy dentin is severely weakened, losing its capacity to support enamel. ${ }^{56}$ Furthermore, it has been said that the use of fluorides does not improve the microhardness of the tissue after irradiation. ${ }^{56,58,63}$

Kielbassa et al evaluated the effects of radiation on dentin microhardness and found that within the limits of an in vitro study, dentin is severely affected by radiation, which may be a feasible explanation for the side effects of radiotherapy, such as gap formation at the amelo-dentinal junction, and radiation-related caries in the cervical region of teeth. ${ }^{63}$

Mellara et al evaluated the effects of radiation therapy on enamel and dentin microhardness in primary teeth $(n=12)$, before and after each 10 Gy of irradiation up to a dose of $60 \mathrm{~Gy}$. They found that enamel microhardness, as a whole, increased ( $p<0.05$ ) after a dose of $60 \mathrm{~Gy}$, particularly in superficial enamel. There was significant difference in microhardness between the nonirradiated dentin in comparison with dentin irradiated with doses of 10, 20, 30 and $40 \mathrm{~Gy} .{ }^{66}$ At $60 \mathrm{~Gy}$, there was no significant difference between the irradiated and nonirradiated dentin. The groups irradiated with doses of 30 and 60 Gy presented better surface alterations in enamel and dentin, in comparison with the nonirradiated groups. With the increase in radiation dose, there was progressive rupture of the enamel and dentin morphology. ${ }^{66}$

A qualitative study using polarized light microscopy and scanning electron microscopy to analyze teeth extracted from irradiated patients showed a reparative dentin, which demonstrated that irradiated dentin can respond to aggressions, such as radiation-related caries. ${ }^{48}$ 
It has been shown that the pattern of demineralization and susceptibility to caries in irradiated dentin is equivalent to that of non-irradiated dentin. ${ }^{48,67,68}$

Knowing the composition of dentin and its large amount of organic components, and the fact that the organic part of dental tissues is more susceptible to the effects of radiotherapy, there are two possible lines of thought. One is that the effect of ionizing radiation on the collagen fibrils possibly does not play a crucial role in the development of radiation-related caries, considering that the onset of radiation caries has been seen to be very similar to development of regular caries in sound teeth. ${ }^{38-42}$ The other line is that the alterations that occurred in dentin after irradiation may result from the damage caused to the collagen fibrils, which led to a significant fall in hardness, wear resistance, amelodentinal junction stability and tensile strength. ${ }^{11}$ These results may justify the appearance of radiation caries at the dentin-enamel junction, since the interruption of the dentin-enamel junction would lead to gap formation and microbial colonization. ${ }^{4}$

\section{Dental Adhesion to Irradiated Tissues}

When it comes to adhesion, there are both in vitro and in situ studies that show that the bond strength of dental materials to irradiated teeth is not impaired by the different amounts of energy coming from radiotherapy.

An in vitro study compared four different adhesive systems on sound dentin, and dentin irradiated with 60 Gy. The result indicated no influence of radiation on any adhesive system. ${ }^{43}$ The same was found when Galetti et al, in a study using sound teeth and teeth extracted from irradiated patients (60-70 Gy), tested three different adhesive systems. ${ }^{69}$ They concluded that there was no difference between the two types of substrate and the three adhesive systems used. Although irradiation was capable of changing the microhardness and collagen matrix, these changes were not enough to interfere in the bond strength between the dentin and adhesive. ${ }^{69}$

Furthermore, Soares et al in an in vitro study, with $60 \mathrm{~Gy}$ and an all-etch adhesive system, tested the bond strength with different directions-either parallel or perpendicular of the dentinal tubules and prisms. ${ }^{53}$ The authors found that irradiated teeth presented decreased bond strength values irrespective of the direction of the tubules and prisms. ${ }^{53}$

Lastly, Naves et al studied the bond strength of irradiated dentin in vitro when the adhesive system was used either before or after irradiation with $60 \mathrm{~Gy} .{ }^{41}$ The result showed that when the adhesive was used before irradiation, there were no statistical differences when the results were compared with those of sound teeth. However, when the adhesive procedures were performed after irradiation, the bond strength was decreased. It was supposed that the dentin must have suffered effects that impaired the bond strength, probably in the hybrid layer. ${ }^{41}$

\section{Osteoradionecrosis}

Osteoradionecrosis (ORN), a late radiation damage to bone and the vascular system, is characterized by inadequate bone repair, since radiation reduces the potential for tissue vascularization. The resulting tissue conditions of hypoxia and hypovascularity can damage cellular activity, collagen formation and tissue healing capacity. ${ }^{70-73}$

Changes in mature bone related to radiotherapy include osteoradionecrosis, pathological fractures, atrophy and radiation-induced neoplasia. ${ }^{74}$ Osteoradionecrosis can present as small asymptomatic bone manifestations, which can remain stable for months or years or heal with conservative treatment; or severe necrosis, which requires surgery and reconstruction. ${ }^{8}$ Some prospective studies have shown that irradiated bone induces bone damage leading to endocarditis, hypocellularity, hypoxia and hypovascularization, creating a predisposition to necrosis with less trauma over time. ${ }^{75}$

The osteoradionecrosis presents more frequently in the mandible, because of the lower blood supply when compared to the maxilla, and also because patients with head and neck cancer (HNC) are inevitably exposed to high doses of radiation when the tumor is near the jaw. ${ }^{76,77}$

Reuther et al, in a 30-year period, evaluated 830 patients with CCP and suggested that the tumor stage, and bone infiltration adjacent to extractions are the most important risk factors for the development of osteoradionecrosis. ${ }^{78}$

Store et al, by means of DNA-DNA hybridization, demonstrated that a wide variety of bacterial species may play a key role in the pathophysiology of osteoradionecrosis and the teeth present within the irradiation field may represent a gateway to microorganisms. ${ }^{79}$

Clinically, mandibular osteoradionecrosis may have pain, swelling, trismus, malocclusion, painful mucosal ulcers with evidence of exposed bone sequestration, pathological fracture in more severe cases, and exposed bone with oral fistula formation. ${ }^{80}$

Since the abnormality of the soft tissue can be interpreted as tumor recurrence, typical imaging examinations should be performed to determine whether the abnormality is mandibular bone osteoradionecrosis or not. These include changes in bone density, cortical 
disruption, disorganization of the trabecular bone and bone fragmentation. ${ }^{70,81}$

From the histological point of view, there is evidence of reduction or obliteration of the vessel lumina and sclerotic changes in their walls, reduction in number and width of the bone trabeculae with increased marrow spaces, which may contain necrotic debris and sometimes bone formation. ${ }^{82}$

Currently, osteoradionecrosis has an annual prevalence rate of approximately $5 \%$ in patients irradiated for CCP, while the approximate frequency is $15 \%$ lower than it was 20 years ago, which was observed with the improvement in therapeutic treatments. ${ }^{70}$

Some risk factors associated with the development of osteoradionecrosis are the treatment performed, total dose of radiation, staging and primary tumor site, tumor proximity to the bone, patient's general health, age, trauma associated with surgery, extractions before or after radiotherapy, presence of dental remainders, poor oral hygiene and continuous use of tobacco or alcohol. ${ }^{83}$

As was previously shown, the radiation dose in head and neck regions usually ranges between 40 and $70 \mathrm{~Gy}$, but even lower doses may lead to the development of changes in salivary glands, in the oral microflora, or hypovascularization. ${ }^{71}$ Typically, the risk for developing osteoradionecrosis is associated with medium doses of 50 to $60 \mathrm{~Gy}$, but professionals are always faced with difficulty in the clinical planning of post-radiation dental extractions, because the exact dose of radiation reaching the area surrounding the bone and teeth has not been commonly reported in the literature. ${ }^{76}$

Thorn et al evaluated the clinical characteristics of patients with ORN of the jaws $(n=80)$ and the relationship between the extent of osteoradionecrosis and the irradiation field. It was found that more than half of the cases of osteoradionecrosis started after extraction, while a third of the cases began spontaneously, with $74 \%$ of the patients developing ORN in the first 3 years. The most common site for the development of osteoradionecrosis is the molar region of jaw and all cases of osteoradionecrosis were found in the irradiation field. ${ }^{84}$

\section{CONCLUSION}

Since radiotherapy is a common treatment for head and neck cancer, it is important for dentists to know what to expect and how to treat these patients. Despite the well-known effects of radiation on the oral cavity, such as xerostomia, changes in the oral microflora, oral mucositis and changes in salivary glands structure, it is still necessary to conduct further studies to show the exact interaction of ionizing radiation with hard dental tissues. While radiation-related caries maintain the same pattern of evolution as regular caries, they have a different behavior and clinical aspect. It is known that the effects of ionizing radiation, which occur in saliva, hygiene and dietary changes in oncologic patients, are key factors in the development of radiation-related caries. However, it is not known which changes may occur when ionizing radiation interacts with dentin and enamel, and how these changes would contribute to the onset of radiationrelated caries.

With the increasing survival of patients with head and neck cancer, the need is recognized for proper management of oral toxicities in order to ensure the long-term oral health and general well-being of the patient.

\section{REFERENCES}

1. El-Faramawy N, Ameen R, El-Haddad K, El-Zainy M. Effects of gamma radiation on hard dental tissues of albino rats: investigation by light microscopy. Radiat Environ Biophys 2013 Aug;52(3):375-387.

2. Marta GN, Silva V, Carvalho HA, de Arruda FF, Hanna SA, Gadia R, da Silva JLF, Correa SFM, Abreu CEC, Riera R. Intensity-modulated radiation therapy for head and neck cancer: systematic review and meta-analysis. Radiother Oncol 2014;110(1):9-15.

3. Tauhata L, Salati Ivan P, Di Prinzio R, Di Prinzio, Antoneita R. Radioproteção e Dosimetria: Fundamentos. Rio de Janeiro: IRD/CNEN; 2003. 263 p. (Port)

4. Seikaly H, Jha N, Harris JR, Barnaby P, Liu R, Williams D, McGaw T, Rieger J, Wolfaardt J, Hanson J. Long-term outcomes of submandibular gland transfer for prevention of postradiation xerostomia. Arch Otolaryngol Head Neck Surg 2004 Aug;130(8):956-961.

5. Jham BC, da Silva Freire AR. Oral complications of radiotherapy in the head and neck. Braz J Otorhinolaryngol 2006 Sep-Oct;72(5):704-708.

6. Kielbassa AM, Hinkelbein W, Hellwig E, Meyer-Lückel H. Radiation-related damage to dentition. Lancet Oncol 2006 Apr;7(4):326-335.

7. Nutting CM, Morden JP, Harrington KJ, Urbano TG, Bhide SA, Clark C, Miles EA, Miah AB, Newbold K, Tanay MA, et al. Parotid-sparing intensity modulated versus conventional radiotherapy in head and neck cancer (PARSPORT): a phase 3 multicentre randomised controlled trial. Lancet Oncol 2001;12(2):127136.

8. Lieshout HF, Bots CP. The effect of radiotherapy on dental hard tissue-a systematic review. Clin Oral Investig 2014 Jan; 18(1):17-24.

9. Shannon IL, Trodahl JN, Starcke EN. Remineralization of enamel by a saliva substitute designed for use by irradiated patients. Cancer 1978 May;41(5):1746-1750.

10. Stephens LC, Schultheiss TE, Price RE, Ang KK, Peters LJ. Radiation apoptosis of serous acinar cells of salivary and lacrimal glands. Cancer 1991 Mar 15;67(6):1539-1543.

11. Garg AK, Malo M. Manifestations and treatment of xerostomia and associated oral effects secondary to head and neck radiation therapy. J Am Dent Assoc 1997 Aug;128(8): 1128-1133. 
12. Nagler RM. The enigmatic mechanism of irradiation-induced damage to the major salivary glands. Oral Dis 2002 May; 8(3):141-146.

13. Aguiar GP, Jham BC, Magalhães CS, Sensi LG, Freire AR. A review of the biological and clinical aspects of radiation caries. J Contemp Dent Pract 2009 Jul 1;10(4):83-89.

14. Kielbassa AM, Hellwig E, Meyer-Lueckel H. Effects of irradiation on in situ remineralization of human and bovine enamel demineralized in vitro. Caries Res 2006;40(2):130-135.

15. Eliasson L, Carlén A, Almståhl A, Wikström M, Lingström P. Dental plaque $\mathrm{pH}$ and micro-organisms during hyposalivation. J Dent Res 2006 Apr;85(4):334-338.

16. Epstein JB, Freilich MM, Le ND. Risk factors for oropharyngeal candidiasis in patients who receive radiation therapy for malignant conditions of the head and neck. Oral Surg Oral Med Oral Pathol 1993 Aug;76(2):169-174.

17. Llena-Puy C. The role of saliva in maintaining oral health and as an aid to diagnosis. Med Oral Pathol Oral Cir Bucal 2006 Aug;11(5):E449-455.

18. Viet CT, Corby PM, Akinwande A, Schmidt BL. Review of preclinical studies on treatment of mucositis and associated pain. J Dent Res 2014 Sep;93(9):868-875.

19. Walker MP, Wichman B, Cheng AL, Coster J, Williams KB. Impact of radiotherapy dose on dentition breakdown in head and neck cancer patients. Pract Radiat Oncol 2011;1(3):142-148.

20. Beumer J, Curtis TA, Nishimura R. Maxillofacial rehabilitation: prosthodontic and surgical considerations. Prosthodontic Procedures: Complete Dentures; St Louis: Ishiyaku Euro America Inc; 1996. p. 101-102.

21. Beumer J, Curtis TA, Nishimura R. Maxillofacial rehabilitation: prosthodontic and surgical considerations. Preradiation Extractions: Current Philosophies and Literature Review, St Louis: Ishiyaku Euro America Inc; 1996. p. 74-78.

22. Ord RA, Blanchaert RH Jr. Current management of oral cancer. A multidisciplinary approach. J Am Dent Assoc 2001;132 suppl:19S-23.

23. Lovelace TL, Fox NF, Sood AJ, Nguyen SA, Day TA. Management of radiotherapy-induced salivary hypofunction and consequent xerostomia in patients with oral or head and neck cancer: meta-analysis and literature review. Oral Surg Oral Med Oral Pathol Oral Radiol 2014 May;117(5):595-607.

24. Vissink A, Panders AK, Gravenmade EJ, Vermey A. The causes and consequences of hyposalivation. Ear Nose Throat J 1988 Mar;67(3):166-168.

25. Andrews N, Griffiths C. Dental complications of head and neck radiotherapy: Part 1. Aust Dent J 2001 Jun;46(2):88-94.

26. Bonan PR, Pires FR, Lopes MA, Di Hipólito O Jr. Evaluation of salivary flow in patients during head and neck radiotherapy. Pesqui Odontol Bras 2003 Apr-Jun;17(2):156-160.

27. Möller P, Perrier M, Ozsahin M, Monnier P. A prospective study of salivary gland function in patients undergoing radiotherapy for squamous cell carcinoma of the oropharynx. Oral Surg Oral Med Oral Pathol Oral Radiol Endod 2004; 97(2):173-189.

28. Beumer J 3rd, Curtis T, Harrison RE. Radiation therapy of the oral cavity: sequelae and management, part 1 . Head Neck Surg 1979 Mar-Apr;1(4):301-312.

29. Rothwell BR. Prevention and treatment of the orofacial complications of radiotherapy. J Am Dent Assoc 1987 Mar; 114(3):316-322.

30. Epstein JB, Freilich MM, Le ND. Risk factors for oropharyngeal candidiasis in patients who receive radiation therapy for malignant conditions of the head and neck. Oral Surg Oral Med Oral Pathol 1993 Aug;76(2):169-174.

31. Al-Tikriti U, Martin MV, Bramley PA. A pilot study of the clinical effects of irradiation on the oral tissues. Br J Oral Maxillofac Surg 1984 Apr;22(2):77-86.

32. Sciubba JJ, Goldenberg D. Oral complications of radiotherapy. Lancet Oncol 2006 Feb;7(2):175-183.

33. Saunders DP, Epstein JB, Elad S, Allemano J, Bossi P, van de Wetering MD, Rao NG, Potting C, Cheng KK, Freidank A, et al. Systematic review of antimicrobials, mucosal coating agents, anesthetics, and analgesics for the management of oral mucositis in cancer patients. Support Care Cancer 2013 Nov;21(11):3191-3207.

34. Lalla RV, Bowen J, Barasch A, Elting L, Epstein J, Keefe DM, McGuire DB, Migliorati C, Nicolatou-Galitis O, Peterson DE, et al. MASCC/ISOO clinical practice guidelines for the management of mucositis secondary to cancer therapy. Cancer 2014 May 15;120(10):1453-1461.

35. Denham JW, Peters LJ, Johansen J, Poulsen M, Lamb DS, Hindley A, O'Brien PC, Spry NA, Penniment M, Krawitz H, et al. Do acute mucosal reactions lead to consequential late reactions in patients with head and neck cancer? Radiother Oncol 1999 Aug;52(2):157-164.

36. Bossola M. Nutritional interventions in head and neck cancer patients undergoing chemoradiotherapy: a narrative review. Nutrients 2015 Jan 5;7(1):265-276.

37. Vissink A, Jansma J, Spijkervet FK, Burlage FR, Coppes RP. Oral sequelae of head and neck radiotherapy. Crit Rev Oral Biol Med 2003;14(3):199-212.

38. Springer IN, Niehoff $P$, Warnke PH, Böcek G, Kovács G, Suhr M, Wiltfang J, Açil Y. Radiation caries-radiogenic destruction of dental collagen. Oral Oncol 2005;41(7):723-728.

39. Sweeney WT, Elzay RP, Levitt SH. Histologic effect of fractionated doses of selectively applied 60 Co irradiation on the teeth of albino rats. J Dent Res 1977;56(11):1403-1407.

40. Saad AY,Abdelazim AA, el-Khashab MM, Mansour MA.Effects of gamma radiation on incisor development of the prenatal albino mouse. J Oral Pathol Med 1991 Sep;20(8):385-358.

41. Naves LZ, Novais VR, Armstrong SR, Correr-Sobrinho L, Soares CJ. Effect of gamma radiation on bonding to human enamel and dentin. Support Care Cancer 2012 Nov;20(11):2873-2878.

42. Silva AR, Alves FA, Antunes A, Goes MF, Lopes MA. Patterns of demineralization and dentin reactions in radiation-related caries. Caries Res 2009;43(1):43-49.

43. Spak CJ, Johnson G, Ekstrand J. Caries incidence, salivary flow rate and efficacy of fluoride gel treatment in irradiated patients. Caries Res 1994;28(5):388-393.

44. Epstein JB, van der Meij EH, Emerton SM, Le ND, StevensonMoore P. Compliance with fluoride gel use in irradiated patients. Spec Care Dentist 1995;15(6):218-222.

45. De Moor RJ, Stassen IG, van't Veldt Y, Torbeyns D, Hommez GM. Two-year clinical performance of glass ionomer and resin composite restorations in xerostomic head- and neck-irradiated cancer patients. Clin Oral Investig 2011 Feb;15(1):31-38.

46. Jansma J, Vissink A, Gravenmade EJ, Visch LL, Fidler V, Retief DH. In vivo study on the prevention of postradiation caries. Caries Res 1989;23(3):172-178.

47. Jansma J, Vissink A, Young BWL, Gravenmade EJ. Xerostomiarelated caries. Dutch J Dent 1992;99:225-232. 
48. Silva AR, Alves FA, Berger SB, Giannini M, Goes MF, Lopes MA. Radiation-related caries and early restoration failure in head and neck cancer patients. A polarized light microscopy and scanning electron microscopy study. Support Care Cancer 2010 Jan;18(1):83-87.

49. Hu JY, Li YQ, Smales RJ, Yip KH. Restoration of teeth with more-viscous glass ionomer cements following radiationinduced caries. Int Dent J 2002;52(6):445-448.

50. Gernhardt CR, Koravu T, Gerlach R, Schaller HG. The influence of dentin adhesives on the demineralization of irradiated and non-irradiated human root dentin. Oper Dent 2004;29(4):454-461.

51. Mccomb D, Erickson RL, Maxymiw WG, Wood RE. A clinical comparison of glass ionomer, resin-modified ionomer and resin composite restorations in the treatment of cervical caries in xerostomic head and neck radiation patients. Oper Dent 2002;27(5):430-437.

52. Peutzfeldt A, Garcia-Godoy F, Asmussen E. Surface hardness and wear of glass ionomers and compomers. Am J Dent 1997; 10(1):15-17.

53. Soares CJ, Castro CG, Neiva NA, Soares PV, Santos-Filho PC, Naves LZ, Pereira PN. Effect of gamma irradiation on ultimate tensile strength of enamel and dentin. J Dent Res 2010 Feb;89(2):159-164.

54. Pioch T, Golfels D, Staehle HJ. An experimental study of the stability of irradiated teeth in the region of the dentinoenamel junction. Endod Dent Traumatol 1992 Dec;8(6):241-242.

55. Moscovich H, Creugers NH, Jansen JA, Wolke JG. In vitro dentine hardness following gamma-irradiation and freezing. J Dent 1999 Sep;27(7):503-507.

56. Jansma J, Vissink A, Jongebloed WL, Retief DH, Johannes'sGravenmade E. Natural and induced radiation caries: A SEM study. Am J Dent 1993 Jun;6(3):130-136.

57. Kielbassa AM, Schendera A, Schulte-Mönting J. Microradiographic and microscopic studies on in situ induced initial caries in irradiated and nonirradiated dental enamel. Caries Res 2000 Jan-Feb;34(1):41-47.

58. Gonçalves LM, Palma-Dibb RG, Paula-Silva FW, Oliveira HF, Nelson-Filho P, Silva LA, Queiroz AM. Radiation therapy alters microhardness and microstructure of enamel and dentin of permanent human teeth. J Dent 2014 Aug;42(8):986-992.

59. Grötz KA, Duschner H, Kutzner J, Thelen M, Wagner W. New evidence for the etiology of so-called radiation caries. Proof for directed radiogenic damage of the enamel-dentin junction. Strahlenther Onkol 1997 Dec;173(12):668-676.

60. Fränzel W, Gerlach R, Hein HJ, Schaller HG. Effect of tumor therapeutic irradiation on the mechanical properties of teeth tissue. Z Med Phys 2006;16(2):148-154.

61. Jansma J, Borggreven JM, Driessens FC, 's-Gravenmade EJ. Effect of X-ray irradiation on the permeability of bovine dental enamel. Caries Res 1990;24(3):164-168.

62. Gwinnett AJ. Structure and composition of enamel. Oper Dent 1992;suppl 5:10-17.

63. Kielbassa AM, Beetz I, Schendera A, Hellwig E. Irradiation effects on microhardness of fluoridated and non-fluoridated bovine dentin. Eur J Oral Sci 1997 Oct;105(5):444-447.

64. Joyston-Bechal S. The effect of X-radiation on the susceptibility of enamel to an artificial caries-like attack in vitro. J Dent 1985 Mar;13(1):41-44.
65. Kielbassa AM, Wrbas KT, Schulte-Mönting J, Hellwig E. Correlation of transversal microradiography and microhardness on in situ-induced demineralization in irradiated and nonirradiated human dental enamel. Arch Oral Biol 1999 Mar;44(3):243-251.

66. Mellara TS, Palma-Dibb RG, de Oliveira HF, Garcia PaulaSilva FW, Nelson-Filho P, da Silva RA, da Silva LA, de Queiroz AM. The effect of radiation therapy on the mechanical and morphological properties of the enamel and dentin of deciduous teeth—an in vitro study. Radiat Oncol 2014;22:30.

67. Arnold WH, Konopka S, Kriwalsky MS, Gaengler P. Morphological analysis and chemical content of natural dentin carious lesion zones. Ann Anat 2003 Oct;185(5):419-424.

68. de Oliveira Mota CC, Gueiros LA, Maia AM, Santos-Silva AR, Gomes AS, Alves F de A, Leão JC, de Freitas AZ, Goes M, Lopes MA. Optical coherence tomography as an auxiliary tool for the screening of radiation-related caries. Photomed Laser Surg 2013 Jul;31(7):301-306.

69. GalettiR,Santos-Silva AR, Antunes AN, Alves Fde A, Lopes MA, de Goes MF. Radiotherapy does not impair dentin adhesive properties in head and neck cancer patients. Clin Oral Investig 2014 Sep;18(7):1771-1778.

70. Jereczek-Fossa BA, Orecchia R. Radiotherapy-induced mandibular bone complications. Cancer Treat Rev 2002;28(1):65-74.

71. Chrcanovic BR, Reher P, Sousa AA, Harris M. Osteoradionecrosis of the jaws-a current overview: Part 2: dental management and therapeutic options for treatment. Oral Maxillofac Surg 2010;14(2):81-95.

72. Lyons A, Ghazali N. Osteoradionecrosis of the jaws: current understanding of its pathophysiology and treatment. Br J Oral Maxillofacial Surg 2008;46(8):653-660.

73. Verdonck HW, de Jong JM, Granzier ME, Nieman FH, de Baat C, Stoelinga PJ. Intensity-modulated radiation therapy for oropharyngeal cancer: radiation dosage constraint at the anterior mandible. Oral Oncol 2009;45(6):511-514.

74. Meurman JH, Grönroos L. Oral and dental health care of oral cancer patients: hyposalivation, caries and infections. Oral Oncol 2010;46(6):464-467.

75. Tribius S, Bergelt C. Intensity-modulated radiotherapy versus conventional and $3 \mathrm{D}$ conformal radiotherapy in patients with head and neck cancer: is there a worthwhile quality of life gain? Cancer Treat Rev 2011;37(7):511-519.

76. Epstein JB, Thariat J, Bensadoun RJ, Barasch A, Murphy BA, Kolnick L, Popplewell L, Maghami E. Oral complications of cancer and cancer therapy. From cancer treatment to survivorship. CA Cancer J Clin 2012;62(6):400-422.

77. Marx RE. Osteoradionecrosis: a new concept of its pathophysiology. J Oral Maxillofac Surg 1983;41(5):283-288.

78. Reuther T, Schuster T, Mende U, Kübler A. Osteoradionecrosis of the jaws as a side effect of radiotherapy of head and neck tumour patients-a report of a thirty year retrospective review. Int J Oral Maxillofac Surg 2003;32(3):289-295.

79. Store G, Eribe ER, Olsen I. DNA-DNA hybridization demonstrates multiple bacteria in osteoradionecrosis. Int J Oral Maxillofac Surg 2005;34(2):193-196.

80. Rayatt SS, Mureau MAM, Hofer SOP. Osteoradionecrosis of the mandible: Etiology, prevention, diagnosis and treatment. Ind J Plast Surg 2007;40(12):65-71. 
81. Debnam JM. Imaging of the head and neck following radiation treatment. Pathol Res Int 2011;2011:Article ID 607820.

82. Pagare SS, Khosa SK. Osteoradionecrosis. Int J Head Neck Surg 2011;2(1):27-32.

83. Hansen HJ, Maritim B, Bohle GC 3rd, Lee NY, Huryn JM, Estilo CL. Dosimetric distribution to the tooth-bearing regions of the mandible following intensity-modulated radiation therapy for base of tongue cancer. Oral Surg Oral Med Oral Pathol Oral Radiol 2012;114(2):e50-54.

84. Thorn JJ, Hansen HS, Specht L, Bastholt L. Osteoradionecrosis of the jaws: clinical characteristics and relation to the field of irradiation. J Oral Maxillofac Surg 2000;58(10):1088-1093. 